\title{
Male Sexual Disorders of Patients with Cancer in Medical Oncology Service in University Hospital of Brazzaville
}

\author{
Judith Nsondé Malanda ${ }^{1}$, Roland Banga-Mouss ${ }^{2}$, Chellet Bilquis Bambi ${ }^{1}$, \\ Aubierge Victoire Kimpamboudi Matondo ${ }^{3}$, Inès Frédérique Nsondé Mondzié ${ }^{1}$, \\ Bab Salam Ngouaka ${ }^{4}$, Siméon Stéphane Moubié ${ }^{5}$ \\ ${ }^{1}$ Carcinology Service University Hospital in Brazzaville, Brazzaville, Congo \\ ${ }^{2}$ Urology Service and Andrology Service University Hospital in Brazzaville, Brazzaville, Congo \\ ${ }^{3}$ Surgery Service Makelekele Hospital Brazzaville, Brazzaville, Congo \\ ${ }^{4}$ Medicine Service Makelekele Hospital Brazzaville, Brazzaville, Congo \\ ${ }^{5}$ Carcinology Service Military Central Hospital P. M Brazzaville, Brazzaville, Congo \\ Email address: \\ drjmalandam@yahoo.fr (J. N. Malanda)
}

\section{To cite this article:}

Judith Nsondé Malanda, Roland Banga-Mouss, Chellet Bilquis Bambi, Aubierge Victoire Kimpamboudi Matondo, Inès Frédérique Nsondé Mondzié, Bab Salam Ngouaka, Siméon Stéphane Moubié. Male Sexual Disorders of Patients with Cancer in Medical Oncology Service in University Hospital of Brazzaville. International Journal of Clinical Oncology and Cancer Research. Vol. 6, No. 3, 2021, pp. 118-124. doi: 10.11648/j.ijcocr.20210603.13

Received: July 8, 2021; Accepted: July 16, 2021; Published: July 23, 2021

\begin{abstract}
Considered as taboo, sexual difficulties and couple intimacy remain rarely tackled by patients and again less by the oncologist practicians. It might seem that faced with the vital stake of disease, this kind of worries seem to be frivolous, indeed shameful to be tackled. The current study had an objective to assess the impacts of cancer on male sexuality followed and treated in medical service in University Hospital of Brazzaville. Studying male sexual disorder of patients with cancer in medical oncology service in university hospital of Brazzaville. It was a retrospective study, from April $1^{\text {st }}$ to July $31^{\text {st }} 2018$. All patients with cancer aged at least 18 years old with a performance of WHO between 0-2 were included. About one hundred (100) patients we examined whose eighty four (84) men, it appears that the most sexual disorder found is the one of craving, then the one of orgasm. Certain troubles had a link with the onset of cancer $(\mathrm{p}<5)$. The men presented a great number of sexual disorder had a cancer of digestive type (47.6\%), urogenital (22.6\%) and soft tissue (19\%). In terms of received treatments: surgery-chemotherapy (men 22\%), chemotherapy only (21.4\%), surgery only (19\%). The global frequency of sexual disorders to all patients is $98.4 \%$ in medical oncology service. It is important to consider those sexual disorders at the time of the care of those patients according to their repercussion on life quality during and after all treatment even in the absence of all progressive nature of disease. The most sexual disorder found is the one of craving.
\end{abstract}

Keywords: Sexual Disorders, Cancer, Craving, Orgasm, Frequency

\section{Introduction}

Every cancer brings a disruption in life patients and their neighborhood [1]. The management of cancerous diseases and their treatments cause physical and psychological change with an impact non negligible on sexual health and intimacy life of patients and partners [2, 3]. Sexual disorders are a consequence which are often underestimated by health staff because longtime assimilated to a "detail" or at best, to a "collateral damage" to survive [4]. The epidemiological reality is we live more and more with the treated cancer, looked after, in remission or cured $[1,5]$. The current study had an objective to assess the impacts of cancer on male sexuality followed and treated in medical service in University Hospital of Brazzaville.

\section{Patients and Methods}

It was a descriptive cross-sectional study with prospective data collection carried out in the carcinology 
service in University Hospital of Brazzaville, in the period from March $1^{\text {st }}$ to August $31^{\text {st }}$ 2018. Most of our population were men over the age of 18 followed for cancer, having a WHO performance status between zero and two and having agreed to take part in the study. We have excluded from this study: patients with disorder of consciousness, those in the terminal phase of cancer disease, those with no sexual activity prior to cancer diagnosis, and those with sexual disorder prior to cancer diagnosis and those with comorbidity associated with cancer such as diabetes or high blood pressure.

The data were collected using a survey form, during an interview with the patient. It contained a questionnaire focusing on the place of the patient's sexuality before and after the diagnosis. The variables studied were age, cancer topography, received treatment, the patient's attitude towards their sexuality (craving, erection quality and orgasm).

\section{Results}

We examined one hundred (100) men with cancer among them, eighty four (84) agreed to answer to our questionnaires. All patients interviewed had sexual activity prior to the discovery of the disease and reported having observed a disruption of their sexual life since the evolution of the disease. Nineteen patients (22.62\%) reported no sexual activity in the last 4 weeks following the survey. The average age was 50 years with the extremes of 20 and 70 years, the median age 49.5 years. The age group 40 and 76 years was the most representative with $87.3 \%$ of cases among them $48.81 \%$ of patients $(\mathrm{n}=41)$ had an age between 40 and 59 years and $28.6 \%(n=24)$ had an age greater than or equal to 60 years. Patients living in couples were in the number of 74 or $88.1 \%$. The half of the patients reported no sexual activity since the announcement of the disease.

Table 1. Distribution of patients in terms of sociodemographic characters.

\begin{tabular}{lll}
\hline & N & \% \\
\hline Age & & 11.9 \\
{$[20-29]$} & 10 & 10.7 \\
{$[30-39]$} & 9 & 27.4 \\
{$[40-49]$} & 23 & 21.3 \\
{$[50-59]$} & 18 & 28.6 \\
{$[60-76]$} & 24 & \\
Marital status & & 11.9 \\
Single & 10 & 15.5 \\
In couple & 13 & 72.6 \\
Married & 61 & \\
Education level & & 1.2 \\
None & 1 & 14.3 \\
Primary & 12 & 19.0 \\
Secondary 1 & 16 & 35.7 \\
Secondary 2 & 30 & 29.8 \\
Higher & 25 & \\
Religion & & 46.4 \\
Catholic & 39 & 22.5 \\
Revival Church & 19 & 14.3 \\
Evangelic & 12 & 6.0 \\
Muslim & 5 & 10.8 \\
Others (1) & 5 & 100.0 \\
Total & 84 & \\
\hline
\end{tabular}

(1) atheist, brahmanism, animist.

Table 2 reports the distribution of patients according to the topography of cancer.

Table 2. Topography of cancer.

\begin{tabular}{|c|c|c|}
\hline Topography & $\mathbf{N}$ & $\%$ \\
\hline Breast & 4 & 4.8 \\
\hline Genito-urinary & 19 & 22.6 \\
\hline Digestive & 40 & 47.6 \\
\hline Respiratory tract high and low & 3 & 3.6 \\
\hline Hematopoietic & 2 & 2.4 \\
\hline Others $^{(1)}$ & 16 & 19.0 \\
\hline Total & 84 & 100.0 \\
\hline
\end{tabular}


Table 3. Distribution of men in terms of sexual disorders and type of cancer.

\begin{tabular}{|c|c|c|c|c|}
\hline Troubles / Organs & Digestives & Urogenitals & Soft tissue & Others* \\
\hline \multicolumn{5}{|l|}{ Craving } \\
\hline Very low & 2 & 2 & 3 & 3 \\
\hline Low & 6 & 2 & 1 & \\
\hline Normal & - & - & - & - \\
\hline \multicolumn{5}{|l|}{ Erection } \\
\hline Severe & 3 & 1 & 3 & 2 \\
\hline Moderately severe & 4 & 3 & - & - \\
\hline Slightly to moderately severe & 1 & - & - & \\
\hline Slightly severe & - & - & - & - \\
\hline Normal & - & - & - & - \\
\hline \multicolumn{5}{|l|}{ Orgasm } \\
\hline Very altered & 5 & 3 & 3 & 1 \\
\hline Altered & 2 & - & - & - \\
\hline Good & - & - & - & - \\
\hline \multicolumn{5}{|l|}{ Global satisfaction } \\
\hline $\mathrm{Bad}$ & 7 & 4 & 3 & 1 \\
\hline Average & 2 & 1 & - & - \\
\hline Good & - & - & - & - \\
\hline \multicolumn{5}{|l|}{ Relational satisfaction } \\
\hline $\mathrm{Bad}$ & 7 & 3 & 3 & 2 \\
\hline Average & 1 & - & - & - \\
\hline Good & - & - & - & - \\
\hline Total & 40 & 19 & 16 & 09 \\
\hline
\end{tabular}

*: breast, melanoma, respiratory tract $\mathrm{p}<1$ (orgasm).

Table 4. Distribution of sexual disorders in terms of received treatment.

\begin{tabular}{|c|c|c|c|c|c|c|c|c|}
\hline & \multicolumn{2}{|c|}{ Libido } & \multicolumn{2}{|c|}{ Erection } & \multicolumn{2}{|c|}{ Orgasm } & \multicolumn{2}{|c|}{ Satisfaction* } \\
\hline & low & normal & low & normal & altered & Normal & No & Yes \\
\hline & n & n & $\mathbf{n}$ & n & n & $\mathbf{N}$ & $\mathbf{N}$ & $\mathbf{N}$ \\
\hline None & 14 & - & 13 & - & 14 & - & 13 & - \\
\hline CT-Surgery & 9 & 1 & 12 & 1 & 14 & 1 & 16 & 1 \\
\hline Chemotherapy & 17 & 1 & 15 & & 13 & 1 & 12 & - \\
\hline Surgery Hormonotherapy & 11 & 1 & 9 & - & 9 & - & 10 & - \\
\hline Surgery-RT & 2 & - & 5 & - & 4 & - & 3 & - \\
\hline Surgery & 12 & 1 & 16 & - & 17 & - & 16 & 1 \\
\hline Hormonotherapy & 12 & - & 8 & - & 7 & - & 9 & - \\
\hline RT & 1 & - & 3 & - & 1 & - & 1 & - \\
\hline Sub total & 80 & 4 & 83 & 1 & 82 & 2 & 82 & 2 \\
\hline Total & 84 & - & 84 & - & 84 & - & 84 & - \\
\hline
\end{tabular}

*Satisfaction with sexual life

Figure 1 permits to record the causes of sexual disorders to men with cancer.

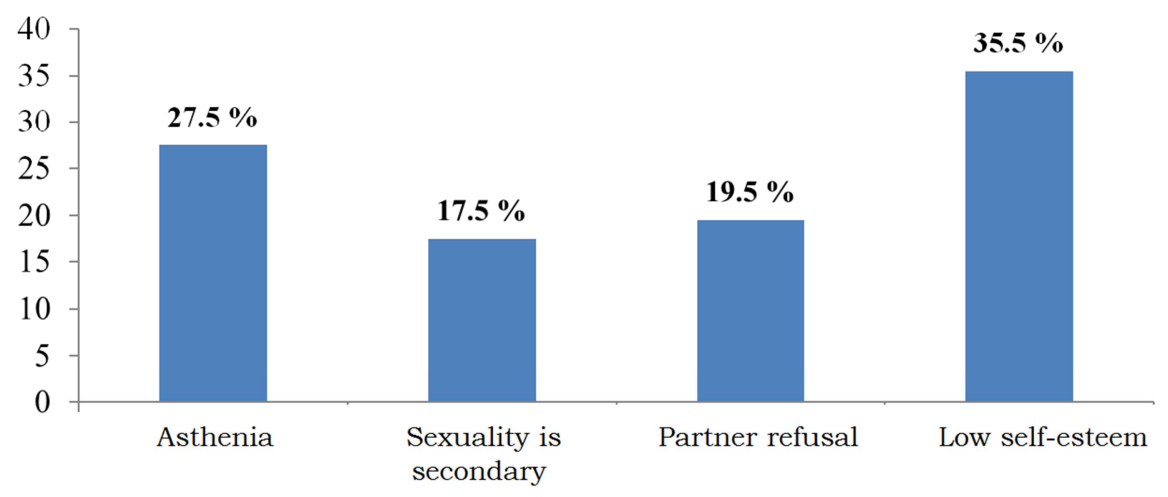

Figure 1. Physical causes and psychological troubles.

Figure 2 permit to make the comparison of sexuality before and after cancer diagnosis. 


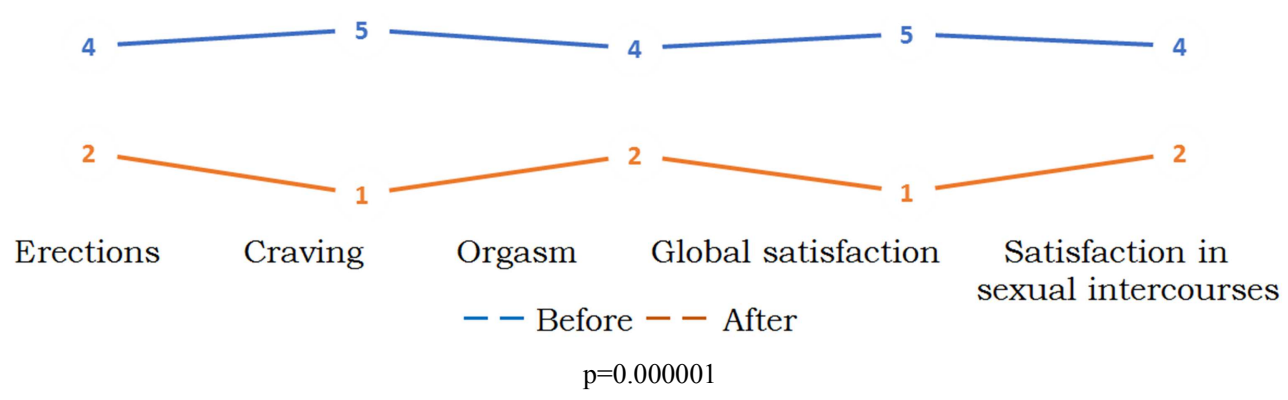

Figure 2. Sexuality before and after cancer diagnosis.

\section{Discussion}

Cancer and its treatments heavily weigh on daily life patients and their neighborhood, with a disruption up to the most intimate spheres, including affective life and sexuality [3].

The announcement of cancer disease is evoked switching in an absolute drama $[5,6]$. The ambiguities that create the fear, anxiety and taboos in cancer pathologies management constitute a limit that aggravate the obstacles caused by the problems linked to sexuality; which still remain to this day considered as a taboo in our regions. While sexuality imply relation, reproduction, life, pleasure, the onset of cancer evokes death, loss, sadness [5]. Bouhnik and coll. [3] have revealed that $35.2 \%$ of people feel less attractive because of their cancer or treatments; they in addition insist that $56.8 \%$ of people report a low of their libido and $53.8 \%$ a low of their capacity having orgasm. Most of sexual problems are not caused by the cancer itself, but by the combination of diverse factors such as depression, anxiety, relationship conflicts, loss of self-esteem [7, 8] and the toxicities of cancer treatment.

Over one hundred (100) patients examined, sixteen (16) refused to take part in the study either by shame because the questions asked were annoying and talking about sexuality bothered them, for others sexuality was not a priority.

All patients who agreed to take part in our study (or answering our questions) reported having a sexual disorder since the disease diagnosis and this topic has never been the subject of consultation as stated by some authors $[1,6,8]$. The patients reported that their sexual craving lowed since the announcement of cancer and especially during the management $[3,8,9]$.

This proves to sufficiency the magnitude of disruption of cancer disease and its treatments on patients' sexuality although they dare not evoking it due to taboo aspect and shame, however sexuality disorders are frequent during cancer disease [10-12].

Limits of study:

1) Patients who agreed to answer questionnaire were those who talking about sexuality was not any problem. For others, they abandoned because the questionnaire were long.

2) The reticence and difficulties to provide relative information to individual sexual practice to an unknown person could influence the correct answers.
3) Some patients have been led to withdraw their consent after giving it beforehand.

Our results require a discussion. Sexuality is a tough access field, which touches what the individual carries with him from the most intimate and identity, a field often forbidden to speak, which not easily allow the expression of the complaint or the decodage of the symptom [3, 5]. Therefore, breaking silence and taboo is important. Sexual health must be an integral part of oncology care. The oncologist is not perceived as the best interlocutor to tackle their scares, vulnerabilities or their sexual narcosis [13, 14]. In the face of communication difficulties, aggraved by myths, fears, taboos and false ideas, the patient await the caregiver to tackle about it and vice versa. Though, the wish to heal or to control cancer with least possible sequels imply to integrate life quality, so, to tackle about health, life and sexual demand $[1,3]$. Nowadays, most of cancers caregivers' underestimate the undeniable expectation of patient information and care of patients as for the aftereffect of their disease on sexual health and intimate life. Physicians are not yet taking sufficient initiave [1].

Lift the silence, legitimize the request and allow it to be spoken to high patients' expectation and are part of good oncology management, because inform about risks and sequelae is an ethical and legal obligation $[10,15]$.

But the most appropriate time to inform the patient is rarely taken into account; this can lead to a patient being considered to be refusing any help while he is in a little receptive period $[1,6]$. Surveys in industrialized countries confirm that many cancer patients are not still informed of potential changes of their sexual function or fertility.

After a treatment against cancer, many patients continue to have unmet needs $[11,12]$ on the matter of restoration of sexual function. The management of sexual disorders can no longer be ignored when difficulties accumulate, a source of despair for the patient and his/her partner $[15,16]$.

The sexual partner sometimes has a share of responsibility in the occurrence of sexuality disorder to the patient [5]. Our study report that $19.5 \%$ of patients related the cause of their sexual disorder to the woman's refusal to engage in sexual activity.

This can be explained by the fact as a result of cancer, the body component becomes more to difficult to manage because often amputed, scarred, inhabited by more or less pleasant prosthesis to endure for oneself or the other (body image altered by stoma) without counting fatigue [16] and 
skin dryness, hair loss, always reminding that you will have to deal with a new person who has lost some of his attributes of symbolics seduction [5].

Physical abnormalities and low hormone levels resulting of gonadal lesion due to anticancer therapy contribute a low self-esteem, to the depression, to a less craving for sexual activity and a decrease in libido [8].

Although the symptoms are often more and more frequent and severe during the treatment, they improve after treatment and may persist for months or years after the treatment [15, 16].

Classically, cancer was the prerogative of the elderly matters, encouraging by ageing. In our study the age of patients was in majority young where the sexual life of patients is active [1]. The same profile is observed to some authors $[1,11,16]$.

Although sexual problems are more and more painful for the less of 65 years [17], among patients sexually active during the diagnostic of cancer $[18,19]$.

Currently, with pharmaco biologic advances in cancer, the more often patient with cancer evolve towards healing [5]. We live longer and longer, with cancer treated, monitored, in remission or healed (almost of 50\% more especially as diagnostic is precoce) $[8,20]$. Improved prognosis is vital of patients with cancer, is the result of the use of several therapeutical means all susceptible to alter life quality and sexuality of patients, in a short or long term [2].

The most therapeutical means administered to patients, were responsible of physical sequela (pain, esthetic damage, dysfunction) and psychological (asthenia, partner refusal, low of self-esteem, secondary sexuality) that what we identified during the surveys. The oncologic treatments have the consequences on sexuality that must be exposed from the outset [5]. We must fight against the preconceived notions that sexuality is a luxury and that the treatment of the disease must place sexuality at the second level $[3,5]$. Unfortunately, the feeling that loss of sex life is a price to pay often shared by many patients, couple and caregivers $[8,14]$.

The disorders of sexual desir, erectile function and a dicrease in the ability to reach orgasm have been reported to high level rate to patients with cancer especially those with prostate cancer $[3,22]$.

The prostate cancer is the second type of diagnostic cancer the most common and which treatments carry out an erectile dysfunction [23] loss of craving and loss of satisfaction orgasmic [24].

Despite technics advanced, the sexual problems remain a side effect omnipresent and painful in prostate cancers treatment [25-27]. In addition to the entire loss of libido and erectile dysfunction, the therapy of androgenic deprivation is associated to a range of side effect such as flushing, tiredness, gynecomastia and emotional lability, which can all affect self-image, perceived identity and maleness experience [22].

The innovations in cancer treatment such as robotic surgery or radiotherapy more targeted had not the expected result to decrease sexual dysfunction [7]. Even among men who had excellence erections beforehand and who are less of
65 years, less of $25 \%$ preserve or recover their old quality of erection [28, 29]. Damage to pelvic nerves, to blood vessel and to structures of orgasms during cancer treatment carry out highest level rate of sexual dysfunction [21, 30], but problems are common even after lung cancer [31], hematologic malignant tumours [32], or of the head or neck [33]. Other side effects of anticancer treatment can lead to the stopping of sexual activity, in particular a persistent tiredness [34], nauseas or urinary incontinence and intestine [35].

It is clear that a story of prostate cancer is a major predictor of sexual dysfunction, even for men under active surveillance.

In the Scandinavian study of group on prostate cancer, with twelve (12) years of monitoring, $84 \%$ men had showed an erectile dysfunction after a radical prostatectomy, as $80 \%$ in active surveillance, against only $43 \%$ of men paired witness who had not prostate cancer [36]. In the United States, the monitoring of 10 years of screening test of prostate cancer, lung, colorectal has revealed that more of $95 \%$ of men of each group of treatment of prostate cancer had erection troubles, and from there, worse than the witnesses [26].

Another prospective study of cohort has recently reported that with 15 years of monitoring, $87 \%$ of men with a localized disease suffered from erectile dysfunction [26].

For some authors like Resnick [37] Bentzen [38] and Kiserud [39] have affirmed that men who have undergone surgery for urologic tumor or rectum, or a radiochemotherapy anal cancer have presented high levels of erectile dysfunction. As for Kiserud and all [39] have affirmed that sexual disorders are not exclusive to men who received treatment at pelvic orgasm stage [39, 40]. Hypogonadism and pelvic nerves lesions can carry out a sexual dysfunction after an intensive chemotherapy, after a malignant blood disease [41]; Herman and Coll. [42], have revealed that, men treated with pelvic radiotherapy or total corporal irradiation, those have presented a sexual dysfunction. The followings with testicle cancer or lymphoma can also have excessive rate of sexual inactivity and a weak craving $[35,43]$. The causes of sexual disorders can be multifactorial, tiredness and negative $[7,41]$.

\section{Conclusion}

Cancer remains a major problem in the field of public health, in spite of many therapeutic advances carried out during these last years. It is proved that it can induce psychological distress which has an impact on patient sexual life and then touch the basis identities, patient seduction, and of self-image.

It emerges that male sexual disorders are very common in patients followed for cancer in carcinology service in University Hospital of Brazzaville. The most sexual disorder found is the one of craving. The attending physician should consider those troubles during the management of patients with cancer, in accordance with their repercussion, on life quality even at the distance of treatment and in the absence of all sign of progressive nature of disease. 
$161-5$

\section{References}

[1] Bondil P, Habold D. Cancer et sexualité: les médecins ne doivent plus faire l'impasse. La lettre du cancérologue 2012 Mar; 21 (3): 165-70.

[2] Ferlay J, Soerjomataram I, Ervik M, Dikshit R, Eser S, Mather $\mathrm{C}$, et al. Cancer incidence and mortality worldwide: Sources, methods and major patterns in GLOBOCAN 2012. $J$ Cancer 2015; 136 (5): 359-86.

[3] Bouhnik AD, Courbiere B, Courtois E, Mancini J, Preau M. Sexualité, vie affective et conjugale. La vie cinq ans après un diagnostic de cancer. Institut National du Cancer 2018: 326-39.

[4] A. Katz, Don S Dizon. Sexuality after cancer: A Model for Male Survivors. J Sex Med. 2016; 13 (1): 70-8.

[5] Patrice Lopès et François-Xavier Poudat. Sexualité au masculin. Manuel de sexologie. Elseiver Paris Masson $2^{\text {ème }}$ édition, 2014; 97-127.

[6] Lemaire A, Alexandre B. Evolution de la personne porteuse d'une pathologie chronique et conséquences sur la sexualité. $J$ sexologies 2006; 15: 108-15.

[7] Schover LR et al. Sexual dysfunction and infertility as late effects of cancer treatment. EJC Suppl 2014; 12 (1): 41-53.

[8] Sadovsky R, Basson R, Krychman M, Morales AM, Schover $\mathrm{L}$, Wang $\mathrm{R}$, et al. Cancer and sexual problems. J Sex Med 2010; 7: 349-73.

[9] Valdivieso M, Kujawa AM, Jones T, al. Cancer Survivors in the United States: A Review of the Literature and a Call to Action. Int J Med Sci 2012; 9 (2): 163-173.

[10] Hautamaki Lammien K, Lipiäinen L, Beaver K, Lehto J et al. Identifying cancer patients with greater need for information about sexual issues. European journal of oncology nursing 2013. 17 (1): 9-5.

[11] Errihani M, Elghissassi I, Mellas N, Belbaraka R, Messmoudi M, Kaikani W. Impact of cancer on sexuality, how is the moroccan patient affected? Sexologies 2009.19 (4): 92-98.

[12] Habold D, Bondil P. Cancers de l'homme et retour à la sexualité. La Lettre du Cancérologue 2010; 29: 170-9.

[13] Park ER, Norris RL, Bober SL. Sexual health communication during cancer care: barriers and recommendations. Cancer $J$ 2009; 15: 74-7.

[14] Pachman DR, Barton DL, Swetz KM et al. Troublesome Symptoms in Cancer Survivors: Fatigue, Insomnia, Neuropathy, and Pain. J Clin Oncol 2012; 30 (30): 3687-96.

[15] Carlsen K, Dalton SO, Frederiksen K, Diderichsen F, Johansen C. Are cancer survivors at an increased risk for divorce? A Danish cohort study. Eur j cancer oxf Engl. 2007; 43 (14) 2093-9.

[16] Hall AE, Boyes AW, Bowman J, Walsh RA, James EL, Girgis A. Young adult cancer survivors' psychosocial well-being: a cross-sectional study assessing quality of life, unmet needs, and health behaviors. Support Care Cancer 2012; 20: 1333-41.

[17] Reese JB, Shelby RA, Abernethy AP. Sexual concerns in lung cancer patients: an examination of predictors and moderating effects of age and gender. Support Care Cancer 2011; 19:
[18] Steinsvik EA, Axcrona K, Dahl AA, Eri LM, Stensvold A, Fossa $^{\circ}$ SD. Can sexual bother after radical prostatectomy be predicted preoperatively? Findings from a prospective national study of the relation between sexual function, activity and bother. BJU Int 2012; 109: 1366-74.

[19] Milbury K, Cohen L, Jenkins R, Skibber JM, Schover LR. The association between psychosocial and medical factors with long-term sexual dysfunction after treatment for colorectal cancer. Support Care Cancer 2013; 21: 793-802.

[20] Bober SL, Sanchez Varela V. sexuality in adult cancer survivors: challenges and intervention. $J$ clin oncol. 2012; 30: 3712-9.

[21] Sanda MG, Dunn RL, Michalski J, et al. Quality of life and satisfaction with outcome among prostate-cancer survivors. $N$ Engl J Med. 2008. 358: 1250-1261.

[22] Potosky AL, Davis WW, Hoffman RM, et al: Five-year outcomes after prostatectomy or radiotherapy for prostate cancer: The prostate cancer outcomes study. J Natl Cancer Inst. 2004. 96: 1358-1367.

[23] van der Wielen GJ, van Putten WL, Incrocci L: Sexual function after three-dimensional conformal radiotherapy for prostate cancer: Results from a dose-escalation trial. Int $J$ Radiat Oncol Biol Phys. 2007. 68: 479-484.

[24] Elliott S, Latini DM, Walker LM, et al: Androgen deprivation therapy for prostate cancer: Recommendations to improve patient and partner quality of life. J Sex Med. 2010. 7: 29963010 .

[25] Lilleby W, Stensvold A, Dahl AA. Intensity-modulated radiotherapy to the pelvis and androgen deprivation in men with locally advanced prostate cancer: a study of adverse effects and their relation to quality of life. Prostate 2013; 73: $1038-47$.

[26] Resnick MJ, Koyama T, Fan KH, Albertsen PC, Goodman M, Hamilton AS, et al. Long-term functional outcomes after treatment for localized prostate cancer. $N$ Engl J Med 2013; 368: 436-45.

[27] Nelson C, Scardino PT, Eastham JA, Mulhall JP. Back to baseline: erectile function recovery after radical prostatectomy from the patients' perspective. J Sex Med 2013; 6: 1636-43.

[28] Den Oudsten BL, Traa MJ, Thong MS, Martijn H, De Hingh $\mathrm{IH}$, Bosscha K, et al. Higher prevalence of sexual dysfunction in colon and rectal cancer survivors compared with the normative population: a population-based study. Eur J Cancer 2012; 48: 3161-70.

[29] Kyrdalen AE, Dahl AA, Hernes E, Sma ${ }^{\circ}$ stuen MC, Fossa ${ }^{\circ}$ SD. A national study of adverse effects and global quality of life among candidates for curative treatment for prostate cancer. BJU Int 2013; 111: 221-32.

[30] Lindau ST, Surawska H, Paice J, Baron SR. Communication about sexuality and intimacy in couples affected by lung cancer and their clinical-care providers. Psychooncology 2011; 20: $179-85$

[31] Thygesen KH, Schjødt I, Jarden M. The impact of hematopoietic stem cell transplantation on sexuality: a systematic review of the literature. Bone Marrow Transplant 2012; 47: 716-24. 
[32] Henry M, Habib LA, Morrison M, Yang JW, Li XJ, Lin S et al. Head and neck cancer patients want us to support them psychologically in the posttreatment period: Survey results. Palliat Support Care 2013, 24.

[33] Strasser F, Palmer JL, Schover LR, Yusuf SW, Pisters K, Vassilopoulou-Sellin R, et al. The impact of hypogonadism and autonomic dysfunction on fatigue, emotional function, and sexual desire in male patients with advanced cancer: a pilot study. Cancer 2006; 107: 2949-57.

[34] Frey AU, Sønksen J, Fode M. Neglected side effects after radical prostatectomy: a systematic review. J Sex Med 2014. 11 (2): 374-85

[35] Johansson E, Steineck G, Holmberg L, Johansson JE, Nyberg T, Ruutu M, SPCG-4 Investigators, et al. Long-term quality of-life outcomes after radical prostatectomy or watchful waiting: the Scandinavian Prostate Cancer Group-4 randomised trial. Lancet Oncol 2011; 12: 891-9.

[36] Taylor KL, Luta G, Miller AB, Church TR, Kelly SP, Muenz $\mathrm{LR}$, et al. Long-term disease-specific functioning among prostate cancer survivors and noncancer controls in the prostate, lung, colorectal, and ovarian cancer screening trial. $J$ Clin Oncol 2012; 30: 2768-75.

[37] Bentzen AG, Balteskard L, Wandera ${ }^{\circ}$ s EH, Frykholm G, Wilsgaard T, Dahl O, et al. Impaired health-related quality of life after chemoradiotherapy for anal cancer: late effects in a national cohort of 128 survivors. Acta Oncol 2013; 52: 73644.
[38] Kiserud CE, Schover LR, Dahl AA, Fossa ${ }^{\circ}$ A, Bjøro T, Loge $\mathrm{JH}$, et al. Do male lymphoma survivors have impaired sexual function? J Clin Oncol 2009; 27: 6019-26.

[39] K K Manier, L S Rowe, J Welsh and Terre B Armstrong. The Impact and incidence of altered body image in patients with head and neck tumors: a systematic review. Neurooncol Pract. 2018; 5 (4): 203-213.

[40] T. Almont, A- Deborah Bouhnik, Ali Ben Charif, Marc- Karim Bendiane, C Couteau, C Manceau, J Mancini E Huyghe. Sexual Health Problems and Discussion in Colorectal Cancer Patients Two Years after Diagnosis: a national Cross-Sectional Study. J Sex Med. 2019; 16 (1): 96- 10.

[41] Herman JM, Narang AK, Griffith KA, Zalupski MM, Reese JB, Gearhart SL, et al. The quality-of-life effects of neoadjuvant chemoradiation in locally advanced rectal cancer. Int J Radiat Oncol Biol Phys 2013; 85: e15-19.

[42] Willemse PM, Burggraaf J, Hamdy NA, Weijl NI, Vossen CY, van Wulften L, et al. Prevalence of the metabolic syndrome and cardiovascular disease risk in chemotherapy-treated testicular germ cell tumour survivors. Br J Cancer 2013; 109: $60-7$.

[43] Recklitis CJ. Sanchez Varela V, Ng A, Mauch P, Bober S. Sexual functioning in long-term survivors of Hodgkin's lymphoma. Psychooncology 2010; 19: 1229-33. 